\title{
THE STUDY ABOUT MANAGEMENT OF COUNSELING AND GUIDANCE PROGRAM IN VOCATIONAL SCHOOL, BANJARMASIN, INDONESIA
}

\author{
Jarkawi; Kasypul Anwar; Zainal Fauzi; and Husnul Madiah \\ Counseling and Guidance Education Department \\ Faculty of Teaching Training and Education \\ Universitas Islam Kalimantan M A B \\ Email: jarkawi010462@gmail.com
}

\begin{abstract}
The counseling and guidance program management as an integral part of education services in school requires the executors to continue in order to improve and develop the service quality. The counseling and guidance have a role to help the learners to be independent, to grow, and to be able to solve their own problems. The implementation of counseling and guidance always undergoes of perfecting. It happens because the problems faced by students always change and get dynamics. The form of activities to do include the socialization of the program to new students, the delivering of materials and services both individual and group, handling students with problems, whether relating to academic problems, personal aspects or violations. While the supervision process includes (a) recording (administration/documentation), (b) evaluation (measurement and assessment of results and work processes and organizational performance), and (c) taking improvement and development step.
\end{abstract}

Keywords: Program Management, Planning, Organization, Implementation, and Controlling

\section{INTRODUCTION}

Education is a conscious effort designed deliberately to prepare the quality of human resource candidates. While national education is a unity that can not be separated in development. Education plays an important role in the development of human resources who have knowledge and skills, have attitude towards everything. Learners are one of the candidates of human resources who have an important role in education because they are the central education services in schools. All activities in the school, whether related to teaching management, education personnel, infrastructure, finance, school relationships with the community and special education services are directed to learners in order to get the maximum education services.

Society believes that education is the womb to give birth to a quality generation, namely the harmonious generation, having physical and spiritual health, having high morality, mastering science and technology professionally, dynamically, and creatively (Yusuf 2012). The effort to give birth to this quality generation not only puts an emphasis on the academic aspect, but also concerns aspects of personal, social, intellectual, values, and religious development. The low appreciation of religion teachings is the factor that affects the students' deviating actions. The facts show that many teens stay away from religious teachings. This happens because of the lack of religious education provided primarily by parents. Religion is only known through lessons at school and they do not implement it in their own life. They are easily swept away by modernization.

In schools, there are some special services for students and one of them is a special service of counseling and guidance. The counseling and guidance services at school are principally to help learners in order to develop self-improvement, attitudes, and good learning habits, to master their skills, to prepare them for continuing education at a higher level. The counseling and guidance are carried out from humans, to humans, and by humans. In everyday life and along with the implementation of education in general, counseling and guidance has its own role in order to provide the guidance to learners. In addition, the implementation of counseling and guidance cannot be separated from the role of the principal, coordination between supervising teachers with teachers in the field of subject, staff/staff, parents, related institutions, and the community. 
The existence of counseling and guidance services aims to develop all learners' potency (Nurihsan, 2012). The emphasis on religious factor in the education system supports activities to achieve the educational goals. The counseling and guidance service in the education system aims to find themselves, to know themselves and to be able to plan their future so that the learners can develop optimally into a whole and independent person (Yusuf 2012). Ruth Strang in Nila Kusmayanti states that counseling is at the heart of the whole business of counseling and guidance services. The goal of counseling and guidance is to do the understanding, the prevention, the poverty reduction, the maintenance, and the development (Sukardi, 2009).

The counseling service provides help the learners to learn about their needs, interests, talents and values based on key life experiences and provide the direction for individuals in order to the find effective ways of learning according to their talents and abilities. The counseling and guidance service at school can be done by organizing a number of counseling activities. The activities will be implemented within the framework of the guidance program. In the program guidance, there are several components, namely formal channels to serve the learners, the parents, and the education personnels (Winkel \& Hastuti 2012: 775).

The counseling and guidance service is in charge of serving normal individuals who are developing themselves optimally in accordance with the stage of development. The counseling and guidance service helps the development of all individual potencies optimally at each stage of development, plays an active role in the formation of productive people. This development will be complemented and enhance the development of intellectual ability and skill with the development of values and attitudes (Wibowo, 2011).

The counseling and guidance service allows individuals to be free from various problems faced in the process of development and life, both community life and state. In this regard, all counseling and guidance services can bridge intellectual development, skills and attitude and value development, as well as the achievement of school education objectives and community needs. It can also fill various vacancies and over- come various problems and individual lives. Thus, counseling and guidance services are a strategic means to enhance the development of a fully qualified individual potency.

The management of counseling and guidance service needs to be formulated in ready manner from the aspect of program planning for counseling and guidance services in order to examine the things required by the students so that the materials provided help students' readiness. The activity and service unit in counseling and guidance can formulate the good counseling and guidance procedures, and evaluate programs that have been implemented. The good and correct guidance and counseling service management can help schools improve the school quality, especially in the development of human resources within the school environment.

Data from Education Office of Banjarmasin City shows that vocational school in quantity has counseling teacher with comparison of 1 guidance and counseling teacher guiding 150 to 200 students with the widest counseling and guidance room and is in accordance with the standard set by BSNP compared to other schools. In quality, the counseling and guidance teachers at vocational school in Banjarmasin City as a pioneer in the establishment of counseling and guidance forum and professional organization of Indonesian Counseling and Guidance Association (are involved in the organization's management both at branch level and active in membership of regional organization.

Based on the above background description, the focus of this research is management on a counseling and guidance service relating to the planning, organizing, implementation, and supervision of counseling and guidance service at vocational school, Banjarmasin.

\section{METHOD}

The method used in this study is descriptive qualitative, which discusses some possibilities to solve actual problems by collecting data, compiling, analyzing, and interpreting. Sugiyono (2012) explains that the descriptive method of analysis is conducted through the description of facts, followed by analysis, providing understanding and explanation. The technique is literature study 
through collecting data by collecting and analyzing documents, either written document, picture or electronic.

\section{RESULT AND DISCUSSION}

\section{The Counseling and Guidance Service Program Planning in Vocational School, Banjarmasin}

The planning of counseling and guidance program in vocational school in Banjarmasin is done with continuous program in order to provide optimization services to students. It is structured based on the needs of students, teachers, principals, and parents. All of them include the needs and functions of counseling and guidance. Yusuf (2012) states that the counseling and guidance program is the effort to provide assistance to the students in order to achieve its development. The planning of counseling and guidance is arranged in accordance with effective, sustainable, open, and appropriate management to anyone in order to receive input without having to change the program already planned. The counseling and guidance program not only focuses on the person in charge of the counseling teacher, but also involves some teachers who have the role of guidance and counselors, principals, counseling teachers, program heads and classroom supervisors. Ani (2012) explains that all the programs planned in counseling and guidance will provide learning achievement to students.

Planning is a preliminary process before entering in the process of program implementation. Programs are planned and organized systematically, organized, and coordinated within a certain timeframe, ie daily, weekly, monthly, and yearly. Based on the findings of the research in vocational school Banjarmasin, the initial step before the implementation process of guidance and counseling personnel services should prepare the student biodata format and data collection of the need for counseling services to the students or commonly called the feasibility study. Tohirin (2007: 260) said that a feasibility study is undertaken to determine the appropriate field and service program for students. Every activity of a program or activity begins with planning because planning is the basic foundation of conducting an activity. In running an activity or program, a ma- ture and clear planning is needed to achieve the objectives. Planning is the whole of the thought process and the careful determination of the things that will be done in the future to achieve the intended purpose (Siagian, 2010).

The planning of guidance and counseling program should be implemented optimally and it involves all concerned parties, such as principals, counseling and guidance teachers, study teachers, staff, parents, school committees, and community leaders. The planning of counseling and guidance program is a process to make a decision about what goals to achieve, what programs and types of services are provided to the students, as well as those who participate in the implementation of the program. This is done to achieve the objectives that have been established effectively and efficiently.

To achieve an objective of effective and efficient guidance and counseling program, Sugiyo (2011: 36) mentions that there are several requirements that must be done: the needs analysis of students, the determination of counseling and guidance goals, situation analysis and condition of the school, the schedule of activity to do, the establishment of a method of implementation of activities, determination of personnel activities, preparation of facilities and cost of activities. The planning process of counseling and guidance service program in vocational school, Banjarmasin starts from problem analysis and students' need in beginning of academic year or end of year by using questionnaire in check list problem, interest talent questionnaire, and sociometry disseminated to students. The environmental analysis and school conditions are also conducted to find out the understanding of school policies, facilities available at school. After the analysis results of the students' needs and the school environment are done, the involvement of stakeholders in the provision of guidance and counseling services as well as infrastructure facilities to support the activities of guidance and counseling services are socialized to all school personnels.

The purpose of counseling and guidance is in line with the school's vision, mission, and goals for student's capacity development optimally in the personal, social, learning and career fields. The overall objectives of counseling guidance services are incorporated into service activities and support activity unit containing 9 types 
of service activities and 4 types of support activities, including individual guidance and counseling techniques and strategies in counseling and guidance room. It is collaborative in the field and classical in the classroom. The results of the planning can be seen from the annual program, semester program, and monthly program implemented in counseling and guidance services in vocational school, Banjarmasin.

\section{Organizing Program of Counseling and Guidance Service in Vocational School, Banjarmasin}

Organizing is an effort to organize the personnel in an organization appropriately and this is an effort to maintain the relationships among these people so that the specified goals can be achieved. In the management of counseling and guidance services in vocational school, organizing is the important factor in order to place the right personnel on every task in the organization of counseling and guidance. This requires good coordination to achieve the organizational goals.

Fattah (2004: 01) explains that the organization has two common senses. First, the organization is defined as an institution or functional group. Second, the organization refers to an organizing process in which the work is organized and allocated among members so that the organizational goals can be effectively achieved. While in manual book on counseling and guidance it is explained that organizing is a form of activities that regulates the work, work procedure, and pattern or working mechanisms of counseling and guidance activity.

Based on the above description, it can be explained that organizing is to describe the election of members and to determine the position, the division of duties, and authority of each member in the implementation of counseling and guidance service program. Organizing is very important to do because in organizing it has been explained about the position, duties, and authority of each member of the program doer. Every member involved in the implementation process of counseling and guidance program should always coordinate and cooperate well so that the stated purpose can be well achieved.

The process of organizing ounseling counseling service officers in vocational school starts from the socialization of the work done by counseling and guidance teachers. This is done in a school co-ordination meeting indirectly, not formally in special meetings. The division of tasks is adjusted to the agreement between the counseling and guidance teachers and it is recorded in the Task Division's Decision Letter from the Principal that is the basis for the division of tasks between counseling and guidance teachers in accordance with the level of class, department and number of students. The division of tasks will be the reference of the division of goals to facilitate teachers in order to carry out their duties in the organization of guidance and counseling aiming to provide services to students as the target.

This division of tasks in vocational school is indicated by the structure of counseling and guidance organizations. Each supervising teacher holds one department by overseeing the activities of the students entering until graduation and so on. This is intended to prevent overlapping of authority within the organization of counseling and counseling.

The coordination and cooperation relationship with stakeholders are made after the program is established. Based on the results of research, the process of socializing the working of counselors and counseling and guidance programs is conducted on certain parties, such as department chiefs, subject teachers and homeroom. In addition to dealing with problem students in violation of the discipline, the mechanism has been running well that is seen from the coordination between disciplinary staff discipline staff, teacher picket, teacher of students and head of department. The coordination process between counselor and stakeholder goes well and this is indicated by the involvement of school personnel with their respective authority which helps the functioning of counseling and guidance organization.

\section{The Implementation of Counseling and Guidance Service Program in Vocational School, Banjarmasin}

Implementation is the next step after the counselor performs planning and organizing. Implementation is the implementation of the program that has been planned. The implementation of counseling and guidance service is at the core of counseling and guidance management. This 
happens because in the implementation counseling and guidance teachers are asked to show the results of their work against their goals, in accordance with the program that has been planned.

Mulyasa (2009: 21) suggests that implementation is an activity to realize the plan to be a real action in order to achieve goals effectively and efficiently. From the whole set of management processes, implementation is the ultimate management function. For the function of a plan, organizing will lead to more abstract aspects of a management process, while the execution function emphasizes activities directly relating to the people within the organization. The process of counseling and guidance program implementation is the realization of guidance and guidance programs that have been planned and arranged in advance to implement effectively and efficiently so that the program runs smoothly.

Each school as an educational unit needs to design a counseling and guidance program as an integral part of the overall school program. The program becomes a reference in implementation of counseling and guidance service at the school. The implementation of counseling and guidance leads to the implementation of planned counseling and guidance program. This is related to annual, semester, and monthly program that correlate with counseling and guidance service, supporting activities of counseling and guidance.

The implementation of counseling and guidance service in vocational school at service activitt unit in program planning is made through placement and distribution service, responsive service, individual counseling, group counseling, group guidance, and mediation. The form of activities are in the form of selection of new students, providing information about various school policies, and facilitating students who have high achievement. The technique of implementing the activities is done by class, group and individual, while the implementation time is done incidentally when there are subject teachers who are unable to attend without any special instructional and counseling hours where it is accorded to the needs. While the implementation of supporting activities of counseling and guidance in the field is adjusted to the program planning that is written in supporting activities units, namely data collection, home visit, referral or handover case, case conference, and cyber counseling.

\section{The Supervision of Counseling and Guidance Services Program in Vocational School}

The supervision of services on counseling and guidance is a mentoring done in order to supervise and assess the activities of counseling and guidance services whether the implementation is in accordance with the planned program. This activity is carried out in the end of program in a management. This activity also aims to identify problems or obstacles that occur during guidance and counseling activities conducted. By knowing the inhibition of the implementation of the activity, the counseling and guidance teachers can find a solution to the problem.

The process of supervision includes (1) recording (administration/recording), (2) evaluation (measurement and assessment of results and work processes and organizational performance); and (3) taking steps of improvement and development (Santoadi 2010: 7). The supervision results of counseling and guidance services in vocational school Banjarmasin starting from recording the work and performance of teachers of guidance and counseling, namely recording daily and weekly activities that are poured in monthly reports. Those are then seen based on the suitability between the program planning made with the implementation of activities undertaken. This is then reported to the principal in the form of a semseter and annual program implementation report for further activities to improve and develop.

\section{CONCLUSION}

Based on the results of the discussion, the management of counseling and guidance in vocational school, Banjarmasin includes program planning, program organizing, program implementation, and supervision of counseling and guidance program. The activities in a planning process consist of (a) the format of biographical data about the student and data collection of the need for counseling services to the students; (b) coordination meetings attended by counseling and guidance personnels, principals, vice principals, teacher of students, and subject teachers; and (c) program socialization.

The process of organizing on counseling and guidance in vocational school, Banjarmasin 
relates to the position of couseling and guidance based on existing organizational structure in that school. It is under the responsibility of the vice principal of student affairs. The selection of members and the determination of position or position of office, and the division of duties and authority of each member in implementation of counseling and guidance program become the authority of counselor of counseling and guidance. The implementation of counseling and guidance program consists of several forms of activities that include the socialization of the program to new students, the provision of materials and services individual and group, handling students with problems, whether relating to academic problems, personal or violations. While the supervision process includes (a) recording (administration/recording), (b) evaluation (measurement and assessment of results and work processes and organizational performance), and (c) taking the improvement and development steps.

\section{REFERENCES}

Catharian T. A. 2012. Need Assesment Model Penyusunan Program Bimbingan dan Konseling Bidang Bimbingan Belajar Berbantuan Sistem Informasi Manajemen di Sma Negeri Kota Semarang. http://journal. unnes.ac.id/sju/index.php/eduman.

Eddy, W. M. 2011. Konseling Kelompok Perkembangan (Development Group Counseling). Semarang: Unnes Press.

Hanurawan, F. 2010. Psikologi Sosial (Social Psychology). Bandung: PT. Remaja Rosdakarya.
Juntika, N. 2012. Landasan Bimbingan dan Konseling (Foundation of Guidance Counseling). Bandung: Remaja Rosdakarya.

Mulyasa, E. 2009. Manajemen Berbasis Sekolah (School Based Management). Bandung: PT Remaja Rosdakarya

Santoadi, F. 2010. Manajemen Bimbingan dan Konseling Komprehensif (Management of Comprehensive Guidance and Counseling). Yogyakarta: USD.

Siagian, S. P. 2010. Filsafat Administrasi (Philosophy of Administration). Jakarta: Gunung Agung.

Sugiyo, 2012. Manajemen Bimbingan dan Konseling di Sekolah Semarang (Management of Guidance and Counseling at School): Widya Karya.

Sukardi, D. K. 2009. Pengantar Pelaksanaan Program Bimbingan dan Konseling di Sekolah (Introduction to Implementation of Guidance and Counseling Program at School). Jakarta: Rineka Cipta.

Tohirin. 2007. Bimbingan dan Konseling di Sekolah dan Madrasah (Berbasis Intregasi) (Guidance and Counseling at School and Madrasah based on Intregation). Jakarta: RajaGrafindo Persada.

Winkel. W.S., \& M.M. Sri H. 2012. Bimbingan dan Konseling di Institusi Pendidikan (Guidance and Counseling in Education Institution). Yogyakarta: Media Abadi.

Yusuf, S. 2012. Landasan Bimbingan dan Konseling (Foundation of Guidance and Counseling). Bandung: PT. Remaja Rosdakarya. 